\title{
High Nuclearity $\mathrm{Cu}$ (II) and Co(II) complexes of Schiff Base Derived from $o$-vanillin with substituted $m$-phenylenediamine
}

\author{
Siti Solihah Khaidir ${ }^{1}$,Hadariah Bahron ${ }^{1}$, Amalina Mohd Tajuddin $^{1}$, Kalavathy Ramasamy ${ }^{2,3}$ and Siong Meng \\ $\operatorname{Lim}^{2,3}$ \\ ${ }^{\text {I}}$ Faculty of Applied Sciences, Universiti Teknologi MARA, 40450 Shah Alam, Selangor, Malaysia \\ ${ }^{2}$ Faculty of Pharmacy, Universiti Teknologi MARA (UiTM), 42300 Bandar Puncak Alam, Selangor, Malaysia \\ ${ }^{3}$ Collaborative Drug Discovery Research (CDDR) Group, Pharmaceutical and Life Sciences Community of Research, Universiti \\ Teknologi MARA (UiTM), 40450 Shah Alam, Selangor, Malaysia \\ *Corresponding author E-mail: s.solihah92@gmail.com
}

\begin{abstract}
In the present work, a polydentate Schiff base ligand (SB) was synthesized via condensation reaction between $o$-vanillin and Cl- $m$ phenylenediamine. Dinuclear complexes of $\mathrm{Co}$ (II) and $\mathrm{Cu}$ (II) were prepared by conventional method with SB:metal ratio of $1: 1$ whereas tetranuclear complexes were obtained via microwave-assisted synthesis with SB:metal ratio of 1:2. Characterization was carried out through elemental analysis $(\mathrm{C}, \mathrm{H}, \mathrm{N})$, molar conductivity, magnetic susceptibility, Fourier Transform Infrared (FTIR), and Nuclear Magnetic Resonance (NMR) spectroscopy. The experimental data indicated that the metal ions of the dinuclear and tetranuclear complexes were coordinated to the ligand through azomethine nitrogen, methoxy oxygen and deprotonated phenolic oxygen. The effective magnetic moment values of $\mathrm{Co}$ (II) complexes suggested tetrahedral geometry with 3 unpaired electrons. The shifting of $v(\mathrm{C}=\mathrm{N}), v(\mathrm{C}-\mathrm{O})_{\text {phenolic }}$ and $v(\mathrm{C}-\mathrm{O})_{\text {methoxy }}$ band to lower frequencies in all complexes indicated that coordination to metal centres occurred through these moieties. New weak peaks in the region $436-559 \mathrm{~cm}^{-1}$ were assignable to $v(\mathrm{M}-\mathrm{N})$ and $v(\mathrm{M}-\mathrm{O})$. SB and its complexes were screened to be positive for anticancer activities against human colon cancer cell (HCT116). Tetranuclear $\mathrm{Cu}_{4} \mathrm{SB}$ and $\mathrm{Co}_{4} \mathrm{SB}_{\text {metal complexes revealed IC }}$ values of 4.2 and 6.87, respectively; indicated to be more potent anticancer agents than the dinuclear counterparts and the parent ligand.
\end{abstract}

Keywords: Schiff base, polynuclear, microwave-assisted, anticancer screening

\section{Introduction}

Complexation of Schiff bases to metals is considered one of the most prominent research areas in the field of coordination chemistry [1]. A great deal of attention in this area has been focused on the complexes because of the presence of two hard donor atoms, nitrogen and oxygen, in the backbones of these ligands. These versatile ligands may act as monodentate, bidentate or polydentate, which can be designed to yield mononuclear [2], dinuclear or polynuclear [3] metal-organic frameworks [4].

It has been reported that Schiff bases are potentially biologically active because of their structural similarities with natural biological substances [5][6] such as porphyrin in heam and chlorophyll. The $(\mathrm{C}=\mathrm{N})$ linkages in Schiff bases is responsible for the biological activities such as antitumor, antibacterial, antifungal and herbicidal activities [7][8]. Based on study by [9] the biological activity of some Schiff base ligands were enhanced upon chelation with metal ions. This is owing to metals which can coordinate with $\mathrm{O}$ or $\mathrm{N}$ - terminals from proteins in a variety of models and retard the activity of the cell. In some cases, however, the free ligands do possess higher activity than the corresponding metal complexes, an indication that activity does not depend solely on the presence of metal ions but rather a synergistic effect of many factors.

Cancer is one of the major global health problems which required

\section{Materials and Method}

\subsection{Materials}

new anticancer drugs. The discovery of cisplatin as an anticancer drug by Rosenberg in 1965, has led to a flurry of investigation of metal-based anticancer agents that can be potentially used in cancer treatments because of their attractive structures and fascinating physicochemical properties. Carboplatin, cisplatin and oxaliplatin are the approved drugs that are used worldwide for treatments of various types of cancer. But these complexes have drawbacks due to their high cost and toxicity to healthy cells causing harmful and undesirable side effects such as nephrotoxicity, neurotoxicity, and emetogensis [10]. Research metal-based anticancer agent were carried out to explore the possible therapeutic potential of new drug entities, also to overcome the hurdles of current clinical drugs including toxicity, and related problems of existing cancer chemotherapeutics

The important criteria for the development of metallodrugs as chemotherapeutic agents are the ability of the metallodrug to bring about DNA cleavage [7]. A large number of transition metal complexes, owing to their redox properties, have been found to promote DNA cleavage thus retard the activity of the cells. The present research work describes the synthesis, characterization and anticancer screening of SB ligand and its dimeric $\mathrm{Cu}$ (II) and $\mathrm{Co}$ (II) complexes containing more than one metal center. The ligand and complexes were characterized via spectroscopic and physicochemical properties. All compounds were evaluated for their activities against colon cancer cell line (HCT116).

The chemicals used in this investigation were of analytical grade. Ortho-vanillin (OVan), Chloro-meta-phenylenediamine (Cl-MPD), copper(II) acetate monohydrate and cobalt(II) acetate tetrahydrate 
were purchased from Sigma Aldrich. All solvents were used as purchased without further purification.

\subsection{Instrumental}

Elemental analysis (carbon, hydrogen and nitrogen) were performed on a Thermo Finnigan Flash EA 110 Elemental Analyzer. Molar conductance of the complexes was recorded in acetonitrile $\left(1 \times 10^{-3} \mathrm{M}\right)$ at room temperature using Mettler Toledo 730 Series conductivity meter, while magnetic measurement was carried out on solid complexes using Sherwood Auto balance. Melting points were determined using a Stuart Melting Point SMP10 apparatus. The IR spectra were recorded as $\mathrm{KBr}$ discs in the range of 4000 $400 \mathrm{~cm}^{-1}$ using Perkin-Elmer FT-IR 1600 spectrometer and reported in $\mathrm{cm}^{-1} .{ }^{1} \mathrm{H}$ NMR spectra were recorded on Bruker Avance 300 MHz. NMR spectrometer. Chemical shifts $(\delta)$ were reported in ppm, relative to the internal standard TMS.

\subsection{Synthesis}

\subsubsection{Synthesis of SB Ligand}

$O$-vanillin (4.5645 g; $30 \mathrm{mmol})$ and $\mathrm{Cl}-m$-phenylenediamine $(2.1389 \mathrm{~g} ; 15 \mathrm{mmol})$ were mixed in $20 \mathrm{~mL}$ of EtOH. The mixture was refluxed for one hour and cooled to room temperature. The brown precipitate yielded was filtered off, washed with cold $\mathrm{MeOH}$ and dried in air before kept in a vial and stored at room temperature. Yield 96.05\%. m.p 196-198 ${ }^{\circ} \mathrm{C}$. Anal. Calc. for $\mathrm{C}_{22} \mathrm{H}_{19} \mathrm{ClN}_{2} \mathrm{O}_{4}$ : C, 64.32; H, 4.66; N, 6.82. Found: C, 64.30, H, $4.62, \mathrm{~N}, 6.77 \%$.

\subsubsection{Synthesis of SB Dinuclear Complexes via Conventional Method}

Dinuclear complexes were prepared by reacting SB $(0.4930 \mathrm{~g} ; 1.2$ $\mathrm{mmol})$ and metal acetate $(1.2 \mathrm{mmol})$ in $20 \mathrm{~mL}$ ethanol and was refluxed for four hours (Fig. 1). The resulting solution was allowed to cool to room temperature upon which colored precipitate was observed in the flask. The precipitate was filtered off, wash several times with cold $\mathrm{EtOH}$ and left to dry in a dessicator over blue silica gel. $\mathrm{Cu}_{2} \mathrm{SB}$ : Yield $29.01 \%$. m.p $300^{\circ} \mathrm{C}<$. Anal. Calc. for $\mathrm{C}_{44} \mathrm{H}_{34} \mathrm{Cl}_{2} \mathrm{Cu}_{2} \mathrm{~N}_{4} \mathrm{O}_{8}\left(\mathrm{CH}_{3} \mathrm{CO}_{2}\right)\left(\mathrm{H}_{2} \mathrm{O}\right)$ : C, 52.23; H, 4.10; N, 5.30. Found: C, 52.55, H, 3.57, N, 6.90\%; $\mathrm{Co}_{2} \mathrm{SB}$ : Yield 37.66\%. m.p $300^{\circ} \mathrm{C}<$. Anal. Calc. for $\mathrm{C}_{44} \mathrm{H}_{34} \mathrm{Cl}_{2} \mathrm{Co}_{2} \mathrm{~N}_{4} \mathrm{O}_{8}\left(\mathrm{H}_{2} \mathrm{O}\right): \mathrm{C}, 55.42 ; \mathrm{H}$, 3.81 ; N, 5.88. Found: C, 55.61, H, 3.86, N, 5.99\%.

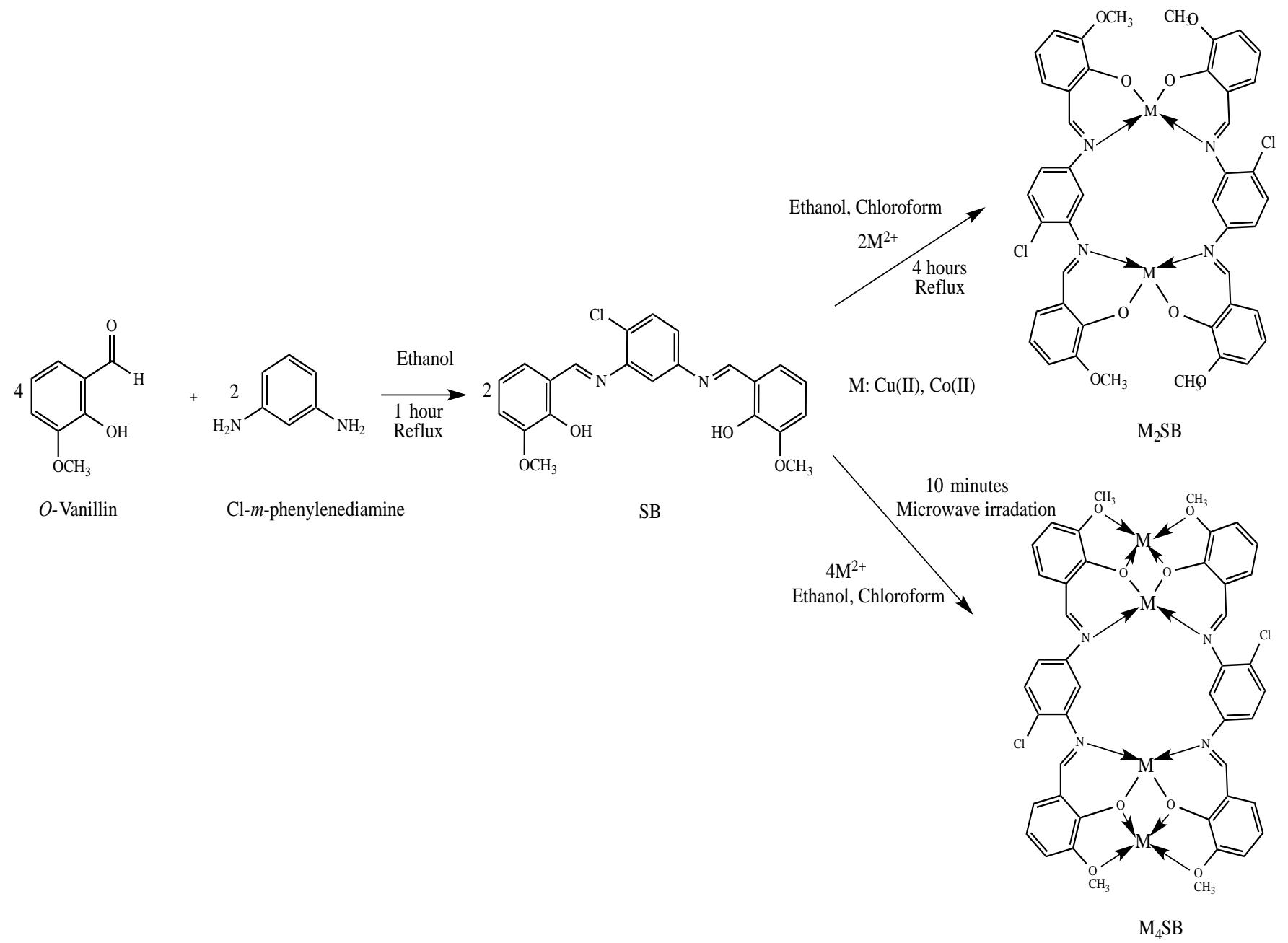

Fig 1: Synthesis of SB ligand, its dinuclear and tetranuclear metal complexes

2.3.3. Synthesis of SB Tetranuclear Complexes via MicrowaveAssisted

Tetranuclear complexes were obtained via microwave-assisted synthesis. SB $(0.3287 \mathrm{~g} ; 0.8 \mathrm{mmol})$ and metal acetate $(1.6 \mathrm{mmol})$ were mixed in ethanol and chloroform mixture (2:1 ratio). $1.3 \mathrm{~mL}$ TEA was added and the mixture was subjected to microwave irradiation at $1000 \mathrm{rpm}$ for 10 minutes (Fig. 1). The mixture was left in a chiller overnight and the obtained colored precipitate was filtered off, washed several times with cold ethanol and left to dry in a desiccator over blue silica gel. $\mathrm{Cu}_{4} \mathrm{SB}$ : Yield 70.97\%. m.p $300^{\circ} \mathrm{C}<$. Anal. Calc. for $\mathrm{C}_{44} \mathrm{H}_{34} \mathrm{Cl}_{2} \mathrm{Cu}_{4} \mathrm{~N}_{4} \mathrm{O}_{8}\left(\mathrm{H}_{2} \mathrm{O}\right)$ : C, 48.49; H, 3.33; N, 5.14. Found: C, 48.91, H, 5.17, N, 6.03\%; $\mathrm{Co}_{4} \mathrm{SB}$ : Yield 31.29\%. m.p $300^{\circ} \mathrm{C}<$. Anal. Calc. for $\left.\mathrm{C}_{44} \mathrm{H}_{34} \mathrm{Cl}_{2} \mathrm{Co}_{4} \mathrm{~N}_{4} \mathrm{O}_{8}\left(\mathrm{CH}_{3} \mathrm{CO}_{2}\right)\left(\mathrm{H}_{2} \mathrm{O}\right)_{3}\right)$ : C, 47.36; H, 3.72; N, 4.80. Found: C, 46.32, H, 3.95, N, 4.52\%. 


\subsection{Anticancer Screening}

\subsubsection{Cell Culture}

The human colorectal carcinoma cell line, HCT116 (ATCC® CCL-247TM), was cultured in the Roswell Park Memorial Institute RPMI 1640 Medium, 25mM HEPES \& L-Glutamine, Biowest, supplemented with $10 \%$ heat inactivated fetal bovine serum (FBS)(PAA Laboratories), and 1\% penicillin/streptomycin, Sigma Aldrich, (St Louis, US). Cultures were maintained in a humidified incubator at $37^{\circ} \mathrm{C}$ in an atmosphere of $5 \% \mathrm{CO} 2$.

\subsubsection{MTT Assay}

HCT116 cells were plated at 7,000 cells per well and allowed to incubate at $37^{\circ} \mathrm{C}$ for $24 \mathrm{~h}$. Schiff base LA and its metal complexes were subjected to serial dilutions before being added to each well. The cells were treated with the compounds at concentrations ranging between $0.01-100 \mu \mathrm{M}$ and incubated at $37^{\circ} \mathrm{C}$ for $72 \mathrm{~h}$. The cytotoxicity of the compounds was assessed using 3-(4,5dimethylthiazol-2-yl)-2,5-diphenyl tetrazolium bromide, Sigma Aldrich, as described by, but with minor modification. Briefly, 50 $\mu \mathrm{L}$ of $0.06 \mathrm{~mol} / \mathrm{L}$ MTT solution (Sigma) was added to each well and plates were incubated at $37^{\circ} \mathrm{C}$ for $4 \mathrm{~h}$. All solutions were aspirated and the formazan crystals were dissolved in dimethylsulfoxide (DMSO)(Merck). The plate was read at $450 \mathrm{~nm}$. Data generated were used to plot a dose-response curve from which the concentration of compounds required to kill $50 \%$ of cell population $\left(\mathrm{IC}_{50}\right)$ was determined [11].

\section{Results and Discussion}

The elemental analysis results were in close agreement with the theoretical values supporting the intended molecular formula and structures as depicted in Fig.1. The melting points of complexes were higher than that of the SB ligand due to the bigger molecular mass and presence of dative bond and ionic bond between metal ion and nitrogen/oxygen donor atoms. The molar conductivity for the complexes was very low indicative of the non-electrolytic nature of the compounds.

\subsection{Magnetic Susceptibility}

For $\mathrm{Cu}_{2} \mathrm{SB}, \mathrm{Co}_{2} \mathrm{SB}, \mathrm{Cu}_{4} \mathrm{SB}$ and $\mathrm{Co}_{4} \mathrm{SB}$ complexes, the magnetic susceptibility measurements were carried out and they were found to be paramagnetic in nature. The $\mathrm{Cu}_{2} \mathrm{SB}$ and $\mathrm{Cu}_{4} \mathrm{SB}$ complexes revealed $\mu_{\text {eff }}$ of 1.82 and 1.88 B.M, respectively, indicative of 1 unpaired electron. Based on this value alone, it is not possible to assign the geometry of the $\mathrm{Cu}$ (II) centres, as all possible geometries would give the same magnetic moment. This observed value is slightly higher than the spin-only value due to the spinorbit coupling followed by lowering of symmetry [12]. The effective magnetic moment values observed for $\mathrm{Co}_{2} \mathrm{SB}$ and $\mathrm{Co}_{4} \mathrm{SB}$ complex were 3.92 and $4.18 \mathrm{BM}$, respectively. These values were expected for the tetrahedral $3 d^{7}$ Co(II) complexes (Lever, 1984) due to three unpaired electrons in the split $d$ orbitals.

\subsection{Infrared Spectroscopy}

The data extracted from the spectra of the ligands and its metal complexes are tabulated in Table 1 and the major bands of the compounds were identified. IR spectra of metal complexes exhibited a broad hump in the region of $3200-3600 \mathrm{~cm}^{-1}$ assigned to $v(\mathrm{O}-\mathrm{H})$ of coordinated water molecules in concordance with the elemental analysis data. A strong vibration peak at $1615 \mathrm{~cm}^{-1}$ for SB ligand, corresponding to $v(\mathrm{C}=\mathrm{N})$ band, was shifted to lower wavenumbers in the region $1610-1611 \mathrm{~cm}^{-1}$ in the metal complexes attributed to the bonding of azomethine $\mathrm{N}$ to metal center, as similarly reported by [13]. It is expected that coordination of nitrogen to the metal centre through a Lewis acid-base interaction would reduce the electron density in the azomethine bond, weakening it, thus lowering the $(\mathrm{C}=\mathrm{N})$ frequency. The peak due to $(\mathrm{C}$ O) phenolic absorption was observed at $1254 \mathrm{~cm}^{-1}$ and the involvement of phenolic $\mathrm{O}$ in the complexation were observed by shifting of this band to lower frequencies around the region of $1240-1249 \mathrm{~cm}^{-1}$ in complexes, in accord with the observation of [14]. The $v(\mathrm{C}-\mathrm{O})$ methoxy stretching frequency of ligand is seen at $1175 \mathrm{~cm}^{-1}$, shifted $4-6 \mathrm{~cm}^{-1}$ to a lower frequency region in the tetranuclear complexes indicating a weaker $\mathrm{C}-\mathrm{O}$ methoxy bond when the lone pair of electrons on $\mathrm{O}$ was shared with the metal center. This was further supported by two new weak bands that appeared in the region of 536-559 $\mathrm{cm}^{-1}$ and $436-447 \mathrm{~cm}^{-1}$ in the spectra of the metal complexes, assigned to $v(\mathrm{M}-\mathrm{O})$ and $v(\mathrm{M}-\mathrm{N})$. In addition to this, a new band was observed at 1592 and 1593 $\mathrm{cm}^{-1}$ in each of the spectra of $\mathrm{Cu}_{2} \mathrm{SB}$ and $\mathrm{Co}_{4} \mathrm{SB}$ metal complexes. These bands represent the stretching of acetate group, and supported that the acetate group coordinated in monodentate fashion.

Table 1 : IR spectral data of Schiff base ligand (SB) and its metal (II) complexes

\begin{tabular}{|c|c|c|c|c|c|c|}
\hline \multirow[b]{2}{*}{ Compd. } & \multicolumn{6}{|c|}{ Frequency $\left(\mathrm{cm}^{-1}\right)$} \\
\hline & $v(\mathrm{C}=\mathrm{N})$ & $\begin{array}{l}v(\mathrm{C}=\mathrm{O}) \\
\text { Acetate }\end{array}$ & $\begin{array}{l}v(\mathrm{C}-\mathrm{O}) \\
\text { Phenolic }\end{array}$ & $\begin{array}{l}v(\mathrm{C}-\mathrm{O}) \\
\text { Methoxy }\end{array}$ & $v(\mathrm{M}-\mathrm{N})$ & $v(\mathrm{M}-\mathrm{O})$ \\
\hline SB & 1615 & - & 1254 & 1227 & - & - \\
\hline $\mathrm{Cu}_{2} \mathrm{SB}$ & 1610 & 1595 & 1246 & 1225 & 543 & 447 \\
\hline $\mathrm{CO}_{2} \mathrm{SB}$ & 1611 & - & 1249 & 1205 & 559 & 447 \\
\hline $\mathrm{Cu}_{4} \mathrm{SB}$ & 1605 & - & 1246 & 1225 & 542 & 444 \\
\hline $\mathrm{Co}_{4} \mathrm{SB}$ & 1614 & 1586 & 1236 & 1221 & 541 & 493 \\
\hline
\end{tabular}

\section{3. ${ }^{1}$ H NMR Spectroscopy}

The peaks of the ${ }^{1} \mathrm{H}$ NMR spectra of SB ligand are listed in Table 2 and shown in Figure 2. $\mathrm{Cu}$ (II) and $\mathrm{Co}$ (II) complexes are paramagnetic compounds preventing a clear NMR analysis because paramagnetic effects will affect the nuclear magnetic shielding tensors, isotropic shielding, chemical shifts, and indirect nuclear spin-spin coupling $(U$-coupling), in nuclear magnetic resonance (NMR) spectroscopy [15]. The SB ligand is not symmetrical due to the presence of the $\mathrm{Cl}$ substituent, causing the peak of each moiety to appear twice. The ${ }^{1} \mathrm{H}$ NMR of SB ligand exhibited two singlet peaks at 13.26 and $12.87 \mathrm{ppm}$ corresponding to $\mathrm{OH}$ proton. The signals at $\delta 9.13$ and $9.06 \mathrm{ppm}$ were attributed to the azomethine proton peak, whereas the two protons of methoxy appeared as a singlet at $\delta 3.84 \mathrm{ppm}$, which integrated for 6 equivalent pro- tons. In the aromatic region, doublets and multiplets, some of which were overlapping were observed in the range of 6.96-7.75 $\mathrm{ppm}$. These signals are due to aryl protons of benzene rings.

Table $2:{ }^{1} \mathrm{H}$ NMR Spectral data of the ligand

\begin{tabular}{|l|c|c|c|}
\hline $\begin{array}{c}\text { Functional group } \\
\text { assigned }\end{array}$ & $\begin{array}{c}\text { Chemical shift } \\
(\mathrm{ppm})\end{array}$ & $\begin{array}{c}\text { Coupling con- } \\
\text { stant, Hz }\end{array}$ & $\begin{array}{c}\text { Number of } \\
\text { protons }\end{array}$ \\
\hline $\mathrm{C}^{1}-\mathrm{OH}$ & $13.26(\mathrm{~s})$ & - & 1 \\
$\mathrm{C}^{21}-\mathrm{OH}$ & $12.87(\mathrm{~s})$ & - & 1 \\
$\mathrm{~N}=\mathrm{C}^{8}-\mathrm{H}$ & $9.13(\mathrm{~s})$ & - & 1 \\
$\mathrm{~N}=\mathrm{C}^{15}-\mathrm{H}$ & $9.06(\mathrm{~s})$ & - & 1 \\
Aromatic & & & \\
$\quad \mathrm{C}^{11}-\mathrm{H}$ & $7.75(\mathrm{~d})$ & 2.4 & 1 \\
$\mathrm{C}^{12}-\mathrm{H}$ & $7.68(\mathrm{~d})$ & 8.5 & 1 \\
$\mathrm{C}^{14}-\mathrm{H}$ & $7.40(\mathrm{dd})$ & $8.5,2.4$ & 2 \\
$\mathrm{C}^{3,5}-\mathrm{H}$ & $7.30-7.23(\mathrm{~m})$ & - & \\
\hline
\end{tabular}




\begin{tabular}{|c|c|c|c|}
\hline $\mathrm{C}^{4}-\mathrm{H}$ & $7.20(\mathrm{dd})$ & $8.0,1.1$ & 1 \\
$\mathrm{C}^{18}-\mathrm{H}$ & $7.17(\mathrm{dd})$ & $8.0,1.0$ & 1 \\
$\mathrm{C}^{17,19}-\mathrm{H}$ & $6.96(\mathrm{~m})$ & - & 2 \\
$\mathrm{OC}^{7,22} \mathrm{H}_{3}$ & $3.84(\mathrm{~s})$ & - & 6 \\
\hline
\end{tabular}

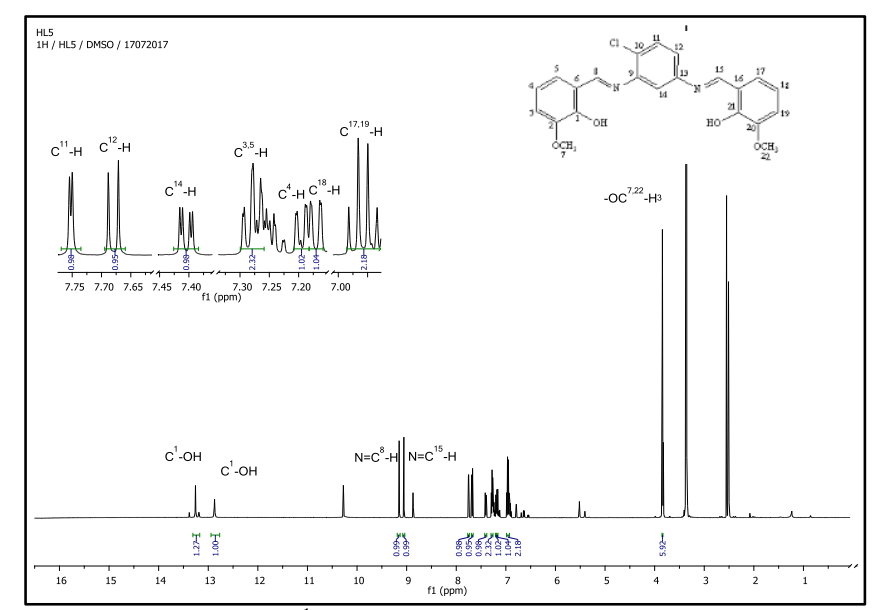

Fig 2: ${ }^{1} \mathrm{H}$ NMR Spectra for SB ligand

\subsection{Anticancer Screening}

The ligand and its corresponding metal complexes were screened for in-vitro anticancer activity. Using DMSO as a negative control, the synthesized compounds were tested for cytotoxicicity activity against colon cancer cell line (HCT116). The graph (Figure 3) shows the dose-response curves of the ligand and its complexes, from which their respective $\mathrm{IC}_{50}$ values tabulated in Table 3 . In general, the tetranuclear compounds demonstrated a good anticancer activity with $\mathrm{Cu}_{4} \mathrm{SB}$ having $\mathrm{IC}_{50}=4.20 \mu \mathrm{M}$ to be the most potent anticancer agent. It was even more potent under the same condition than the standard drug, 5-fluorouracil $\left(\mathrm{IC}_{50}=4.60 \mu \mathrm{M}\right)$, a previous work reported by this group [11]. The $\mathrm{IC}_{50}$ values of $\mathrm{Co}_{4} \mathrm{SB}, \mathrm{Cu}_{2} \mathrm{SB}, \mathrm{Co}_{2} \mathrm{SB}$ and $\mathrm{SB}$ were revealed to be $6.87,12.25$, 22.75 and 78.25 , respectively, in decreasing order of activity. The presence of 4 metal atoms clearly increased the anticancer potential of the synthesized complexes. This suggests that the active sites for the anticancer properties are the metal centres that increased proportionately with the activity. $\mathrm{Cu}$ (II) centres exhibited higher anticancer properties than $\mathrm{Co}$ (II) centres, and the compound without any metal centre i.e. the parent ligand SB, showed the lowest activity.

Table 3: Anticancer activity (IC50 in $\mu \mathrm{M}$ ) of SB with its complexes against HCT 116 cancer cell line

\begin{tabular}{|c|c|}
\hline Compound & $\mathrm{IC}_{50}$ against HCT116 $(\mu \mathrm{M})$ \\
\hline $\mathrm{SB}$ & $78.25(\mathrm{~V})$ \\
\hline $\mathrm{Co}_{2} \mathrm{SB}$ & $22.75(\mathrm{IV})$ \\
\hline $\mathrm{Cu}_{2} \mathrm{SB}$ & $12.25(\mathrm{III})$ \\
\hline $\mathrm{Co}_{4} \mathrm{SB}$ & $6.87(\mathrm{II})$ \\
\hline $\mathrm{Cu}_{4} \mathrm{SB}$ & $4.20(\mathrm{I})$ \\
\hline $5 \mathrm{FU}$ & 4.60 \\
\hline
\end{tabular}

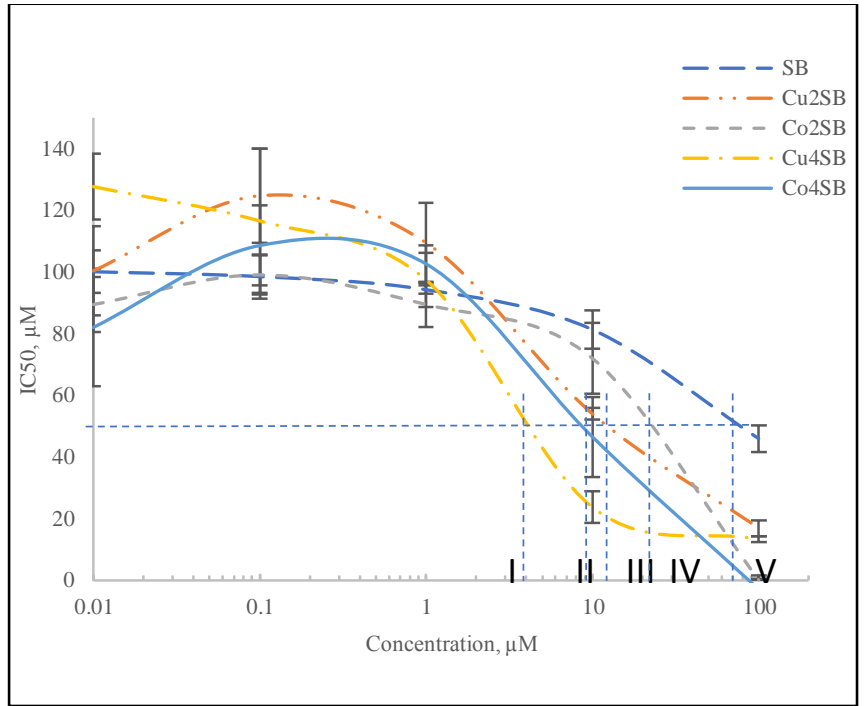

Fig 3 : $\mathrm{IC}_{50}$ dose curve for SB and its complexes

\section{Conclusion}

The $\mathrm{Cu}(\mathrm{II})$ and $\mathrm{Co}(\mathrm{II})$ dinuclear complexes formed in a 1:1 ligand to metal reaction stoichiometry, and $\mathrm{Cu}$ (II) and $\mathrm{Co}$ (II) tetranuclear complexes formed in a 1:2 ligand to metal reaction stoichiometry. All compounds were successfully characterized by elemental analysis, molar conductivity, magnetic subceptibility, IR and NMR spectroscopy. Screening of the ligand and its complexes for anticancer activity against human colon cancer (HCT116) was carried out and $\mathrm{Cu}_{4} \mathrm{SB}\left(\mathrm{IC}_{50}=4.20 \mu \mathrm{M}\right)$ tetranuclear metal complexes was observed to be the most potent anticancer agent.

\section{Acknowledgement}

The authors wish to thank the Malaysian Ministry of Higher Education for the research funding 600-IRMI/MyRA 5/3/BESTARI (034/2017) and the MyBrainSc scholarship. Universiti Teknologi MARA are gratefully acknowledged for the research facilities provided.

\section{References}

[1] Aziz, A. A. A., Salem, A. N. M., Sayed, M. A., \& Aboaly, M. M. (2012). Synthesis, structural characterization , thermal studies , catalytic efficiency and antimicrobial activity of some M ( II ) complexes with ONO tridentate Schiff base. Journal of Molecular Structure, 1010, 130-138.

[2] Tajuddin, A. M., Anouar, E. H., Ramasamy, K., Yamin, B. M., Alharthi, A. I., \& Bahron, H. (2017). DFT analysis and bioactivity of 2-((E)-(4-methoxybenzylimino)methyl)phenol and its $\mathrm{Ni}(\mathrm{II})$ and Pd(II) complexes. Arabian Journal of Chemistry, 10(6), 769-780.

[3] Bahron, H., Khaidir, S. S., Tajuddin, A. M., \& Illah S.A, K. S. . (2017). Synthesis and characterisation of mononuclear and tetranuclear zinc( II ) complexes of Schiff bases derived from phenylenediamine. PERTANIKA Journal of Science and Technology, 25, 309-316.

[4] Dave, S., \& Bansal, N. (2014). Microwave assisted synthesis of schiff bases complexes via eco - friendly greener methodology. International Journal of Basic and Applied Chemical Sciences, 4(1), 58-66.

[5] S. Patai (Ed.), the Chemistry of the Carbon-Nitrogen Double Bond, J. Wiley \& Sons, London, 1970.

[6] Jungreis E and Thabet S (1969). Analytical Applications of Schiff Bases (Marcell Dekker, New York)

[7] Chang, H. Q., Jia, L., Xu, J., Xu, Z. Q., Chen, R. H., Wu, W. N., Wang, Y. (2015). Syntheses, characterizations, antitumor activities and cell apoptosis induction of $\mathrm{Cu}(\mathrm{II}), \mathrm{Zn}$ (II) and $\mathrm{Cd}(\mathrm{II})$ complexes with hydrazone Schiff base derived from isonicotinohydrazide. Inorganic Chemistry Communications, 57, 8-10.

[8] Suresh, \& Prakash. (2011). Preparation characterization and antibacterial studies of chelates of schiff base derived from 4- 
aminoantipyrine, furfural and o-phenylenediamine. E-Journal of Chemistry, 8(3), 1408-1416.

[9] Mounika, K., Pragathi, A., \& Gyanakumari, C. (2010). Synthesis characterization and biological activity of a schiff base derived from 3-ethoxy salicylaldehyde and 2-amino benzoic acid and its transition metal complexes. Journal of Scientific Research, 2(3).

[10] Wong, E., \& Giandomenico, C. M. (1999). Current status of platinum-based antitumor drugs. Chemical Reviews, 99(9), 2451-2466.

[11] Kumar, P., Narasimhan, B., Ramasamy, K., Mani, V., Mishra, R. K., \& Majeed, A. B. A. (2015). Synthesis, antimicrobial, anticancer evaluation and QSAR studies of 3/4-bromo benzohydrazide derivatives. Current Topics in Medicinal Chemistry, 15(11), 1050-64.

[12] Selwin Joseyphus, R., \& Sivasankaran Nair, M. (2010). Synthesis, characterization and biological studies of some $\mathrm{Co}(\mathrm{II}), \mathrm{Ni}$ (II) and $\mathrm{Cu}(\mathrm{II})$ complexes derived from indole-3-carboxaldehyde and glycylglycine as Schiff base ligand. Arabian Journal of Chemistry, 3(4), 195-204.

[13] Sobola, A. O., Watkins, G. M., \& Brecht, B. Van. (2014). Synthesis, characterization and antimicrobial activity of copper(ii) complexes of some ortho-substituted aniline schiff bases; crystal structure of bis(2-methoxy-6-imino)methylphenol copper(ii) complex. South African Journal of Chemistry, 67, 45-51.

[14] Wu, W., Xuan, Y., Yin, J. L., \& Shujie, L. (2014). Synthesis and characterization of a novel o -vanillin schiff base derivatives and their complexes with zn(ii). Synthesis and Reactivity in Inorganic, Metal-Organic, and Nano-Metal Chemistry, 44(6), 877-880.

[15] Autschbach, J. (2015). NMR calculations for paramagnetic molecules and metal complexes. Annual Reports in Computational Chemistry, 11, 3-36. 